\title{
EFFECT OF BACTERIOPHAGE-DERIVED DOUBLE STRANDED RNA ON RAT PERITONEAL MACROPHAGES AND MICROGLIA IN NORMOXIA AND HYPOXIA
}

\author{
Dace Pjanova ${ }^{1, \#}$, Yevheniia Hurmach ${ }^{2}$, Mariia Rudyk ${ }^{2}$, Natalia Khranovska ${ }^{3}$, \\ Oksana Skachkova $^{3}$, Irina Verhovcova ${ }^{1}$, and Larysa Skivka ${ }^{2}$ \\ ${ }^{1}$ Latvian Biomedical Research and Study Centre, 1 Rātsupītes Str., k-1, Rīga, LV-1067, LATVIA \\ ${ }^{2}$ Educational and Scientific Centre, Institute of Biology and Medicine, Taras Shevchenko National University of Kyiv, \\ 64/13 Volodymyrska Str., Kyiv, 01601, UKRAINE \\ ${ }^{3}$ National Cancer Institute, 33/43 Lomonosova Str., Kyiv, 03022, UKRAINE \\ \# Corresponding author: Dace Pjanova, dace@biomed.lu.lv
}

Contributed by Dace Pjanova

\begin{abstract}
The involvement of tissue-resident macrophages (TRMs) in health and diseases makes them unique therapeutic targets. TRMs are activated through their surface pattern recognition receptors, such as Toll-like receptors (TLRs) that are essential sensors of danger signals. Here, we determine the activation status of rat peritoneal macrophages (PMs) and microglia (MG) cells under normal and hypoxic conditions and investigate the effect of TLR3 agonist bacteriophage-derived dsRNA (Larifan) on the metabolic profile of TRMs in vitro. We implemented the phenotypic markers CD14 and CD206, arginine metabolism, phagocytic activity and reactive oxygen species generation as metabolic characteristics to evaluate TRMs activation. We showed that normoxic TRMs from different tissue niches responded to Larifan exposure in different ways. PM exhibited signs towards $M 1$ polarisation. In contrast, the MG activation pattern could be considered as neither pro-inflammatory nor anti-inflammatory. We also showed that TRMs, regardless of the tissue niche, responded to hypoxia with a phenotypic shift towards an anti-inflammatory (M2) state. Larifan could attenuate hypoxia-induced TRMs metabolic programming. However, hypoxic conditions could negatively affect the interaction of TRMs with danger signals.
\end{abstract}

Key words: tissue-resident macrophages, TLR3 agonists, Larifan, phenotypic shift.

\section{INTRODUCTION}

Hypoxia, defined as an inadequacy between $\mathrm{O}_{2}$ supply and demand, is present in various inflamed and diseased tissues. Hypoxia originates due to the congestion of the local blood supply or the inability of local vessel growth to keep pace with the development and/or infiltration of cells in that area. Tissue-resident macrophages (TRMs) accumulate in large numbers in such sites and respond rapidly to hypoxia (Colgan et al., 2020). The dynamic interaction between cells of inflamed tissues, including TRMs, and microenvironmental factors, such as hypoxia and others, substantially determines the pathophysiology of many diseases ranging from infectious diseases to chronic inflammation and cancer. All TRMs originate from embryonic precursors and are main- tained by self-renewal (Hashimoto et al., 2013; Theret et al., 2019).

Nevertheless, macrophages are still characterised by considerable diversity and plasticity. M1-polarised (or classically activated) and M2-polarised (or alternatively activated) macrophages are the extremes of a continuum of functional states (Sica and Mantovani, 2012). M1-polarised macrophages mediate the initiation of inflammatory responses and tissue damage, thus participating in the positive immune response and function as tissue sentinels (Biswas and Mantovani, 2010). M2 macrophages have poor antigenpresenting ability and produce factors that suppress T-cell proliferation and activity. They are better adapted to scavenge for debris, promote angiogenesis and play a key role in 
tissue repair (Gordon and Martinez, 2010). The common core functional programme of all TRMs includes phagocytosis of pathogens, efferocytosis of dying cells, chemokine and cytokine production, etc.

Additionally, the tissue niche where TRMs reside determines their unique features and functions (Caputa et al., 2019). Peritoneal macrophages (PMs) represent one of the most studied TRM populations. PMs play a critical role in the control of infections, inflammatory pathologies and cancer (Dahdah et al., 2014; De Palma et al., 2017; Liu et al., 2018) as well as in the maintenance of immune response robustness (Okabe and Medzhitov, 2016).

PMs derive from progenitors in the embryonic liver, and the metabolic profile of resting PMs is considered as M0 (Zhao et al., 2017).

Microglia (MG), being TRMs of the central nervous system (CNS), form a significant component of the brain immune system. As the resident macrophages of CNS, MG act as the first line of active immune defense (Filiano et al., 2015). The growing number of literature data indicates that MG is a highly unique population of TRMs. These cells originate from the yolk sac and are influenced by the brain's environmental signals. The metabolic profile of resting and activated MG does not fit into the M1/M2 macrophage polarisation pattern, and in normal, non-pathological brain exists as moderately shifted towards M2 phenotype. The reason for this phenomenon is substantially unexplored and probably lies in the epigenomic regulation of MG metabolism (Cherry et al., 2014; Guo et al., 2019; Bennett and Bennett, 2020).

Profound involvement of TRMs in tissue functionality in health and disease makes them unique therapeutic targets. As the first line of host defense against infections, TRMs are activated through their surface pattern recognition receptors (PRR). PRR, such as Toll-like receptors (TLR), are essential sensors of danger signals, including bacterial, fungal, protozoal and viral proteins. TRMs sense these signals via the so-called pathogen-associated molecular patterns (PAMPs) as well as damage-associated molecular patterns (DAMPs) (Suresh and Mosser, 2013). One of the typical PAMPs is the double-stranded RNA (dsRNA) that is often associated with infections either as an intermediate product of virus replication cycle or as a part of virus RNA genome and can also appear in the extracellular environment due to host cell death (Vercammen et al., 2008). Bacteriophagederived dsRNA, also known as Larifan (Larifan Ltd., Rīga, Latvia), is a heterogeneous population of dsRNA molecules that was isolated from Escherichia coli cells infected with the RNA bacteriophage f2 mutant (Loža and Feldmane, 1996; Loža et al., 1996). Larifan is also capable of inducing type (I) interferons (IFN) (Loža and Feldmane, 1996) and recently has been shown to be an effective stimulator of the innate immune system (Pjanova et al., 2019).

In many cases, macrophage response to hypoxia and PAMPs recognition are interdependent. Tissue inflamma- tion due to infection is always associated with the development of the hypoxic condition. Just as inflammation itself can lead to hypoxia, physiologically hypoxic tissues, like intestinal mucosa or brain, exposed to PAMPs can promote inflammation (Jantsch and Schödel, 2015; Taylor and Colgan, 2017). The consequences of the combined effect of these endogenous and exogenous triggers on TRMs have not been extensively explored. Here, we determine the activation status of rat PMs and MG under normal and hypoxic conditions and investigate the effect of TLR3 agonist Larifan on the metabolic profile of these TRMs in vitro.

\section{MATERIALS AND METHODS}

Animals. Intact Wistar rats (male, 2.5 months old), bred in the vivarium of ESC Institute of Biology and Medicine of Taras Shevchenko National University of Kyiv, were used in the study. All procedures with animals were carried out based on ethics principles according to the General Principles of Animal Experimentation approved by the National Congress on Bioethics (Kyiv, 2001-2007) and in accordance with the Council Directive of 24 November 1986 on the approximation of laws, regulations, and administrative provisions of the Member States regarding the protection of animals used for experimental and other scientific purposes (86/609/EEC).

Isolation and culture of rat peritoneal macrophages (PM). Rat PMs were isolated from peritoneal cavity without preliminary stimulation. Briefly, rats were euthanised and PMs were harvested using PBS containing $100 \mathrm{U} / \mathrm{ml}$ of heparin. The cells were then pelleted by centrifugation for 5 minutes at $4{ }^{\circ} \mathrm{C}$ at $300 \mathrm{~g}$, washed twice with serum-free RPMI-1640, and re-suspended in RPMI-1640 containing $10 \% \mathrm{FCS}$ and $40 \mu \mathrm{g} / \mathrm{ml}$ gentamycin. After this, PMs were seeded into 96 -wells flat bottom plates $\left(3 \times 10^{5}\right.$ cells/well $)$ and incubated at $37{ }^{\circ} \mathrm{C}$ in a humidified incubator in $95 \%$ air $/ 5 \% \mathrm{CO}_{2}$ for $2 \mathrm{~h}$ to let the cells adhere. Non-adherent cells were disposed by washing with serum-free RPMI1640, and adherent cells were further cultured with RPMI1640-10\% FCS for hypoxia induction experiments. The trypan blue exclusion test was used in order to determine cell viability. The proportion of viable cells was more than $95 \%$.

Microglia (MG) cell isolation. MG cells were isolated as described by Frank et al. (2006) with slight modifications. Whole brain was placed in cold Dulbecco's PBS (DPBS) supplemented with $0.2 \%$ glucose, and ground into $1-2 \mathrm{~mm}$ pieces using scissors. Tissue pieces were then gently disintegrated in sDPBS using a Potter-Elvehjem tissue homogeniser. Tissue homogenate was then filtered through a $40 \mu \mathrm{M}$ cell strainer (BD Biosciences Discovery, USA) to separate cell aggregates. After this, the cell suspension was centrifuged for $10 \mathrm{~min}$ at $350 \mathrm{~g}$. The pelleted cells were mixed with $1 \mathrm{ml} 70 \%$ isotonic Percoll (Sigma). Two milliliters of $50 \%$ isotonic Percoll was gently layered on top of the $70 \%$ layer and then $1 \mathrm{ml}$ PBS was gently layered on the top of the $50 \%$ Percoll layer. The mixture was then centrifuged at $1200 \mathrm{~g}$ for $45 \mathrm{~min}$. The layer enriched with microglia at the 
interface between the 70 and 50\% isotonic Percoll phases were separated. The cells were pelleted, washed twice with serum-free DPBS, and resuspended in DMEM containing $10 \% \mathrm{FCS}$ and $40 \mu \mathrm{g} / \mathrm{ml}$ gentamycin. The trypan blue exclusion test was used for the determination of cell viability. The proportion of viable cells was more than $96 \%$. In order to assess MG purity by flow cytometry, FITC-conjugated mouse anti-rat CD11b antibodies (BD Pharmingen, USA) and PE-conjugated mouse anti-rat CD45 (BD Pharmingen, USA) were used. The proportion of the CD11b+CD45+ cell fraction was $87.49 \pm 1.34 \%$.

Hypoxia induction and treatment with Larifan. PMs and MG cells were subjected to either normoxia $\left(21 \% \mathrm{O}_{2}\right)$ or hypoxia $\left(3 \% \mathrm{O}_{2}\right)$ for $24 \mathrm{~h}$ as described earlier (Skivka et al., 2013). In brief, normoxia was controlled by using a humidified $5 \% \mathrm{CO}_{2}$ incubator, and hypoxia by resuspending in RPMI-1640 (for PMs) and DMEM (for MG cells) for 30 min in a sealed hypoxic work station with a $5 \% \mathrm{CO}_{2} /$ balance $\mathrm{N}_{2}$ gas mix and subsequent culture in a humidified hypoxic $\left(\mathrm{CO}_{2} / \mathrm{N}_{2}\right)$ incubator. After the incubation, the cells subjected to normoxia were washed three times in a cold calcium/magnesium-free PBS and harvested. For cells incubated in hypoxic conditions, these procedures were carried out in a chamber with a constant flow of $\mathrm{CO}_{2} / \mathrm{N}_{2}$ gas mixture. To verify the actual oxygen concentration in the hypoxia incubators, an oxygen monitor was used. To estimate the effect of Larifan on the metabolic profile and phenotypic marker expression of PMs and MG exposed to normoxia and hypoxia, the cells were treated with Larifan at concentrations of $200 \mu \mathrm{g} / \mathrm{ml}$ (determined previously (Veinalde et al., 2014)) for $24 \mathrm{~h}$ in normoxic and hypoxic conditions, respectively. Conditioned media and cells were harvested after the treatment with Larifan. Aliquots of media were sampled immediately and analysed for nitrites. Arginase activity, phagocytosis and intracellular reactive oxygen species (ROS) generation were analysed in harvested cells. All experiments were carried out in triplicate.

NO metabolite assay. After the cultivation of cells under various conditions tested, the culture supernatants were collected, and the NO metabolite concentration in each supernatant was assayed by Griess reaction (Reiner, 2009). Each value of NO metabolite content was divided by the number of viable cells and expressed as the NO metabolite level per $10^{6}$ cells. Normalised values of means and SDs were calculated.

Determination of arginase activity. Arginase activity was measured in cell lysates by the standard colorimetric method (Reiner, 2009). Briefly, $100 \mu$ of $0.1 \%$ Triton $\mathrm{X}-100$ and $100 \mu \mathrm{l}$ of $50 \mathrm{mM}$ Tris- $\mathrm{HCl}(\mathrm{pH} 7.5)$, containing $10 \mathrm{mM} \mathrm{MnCl}_{2}$, were sequentially added to PM samples. Arginase was then activated by heating the samples at $56^{\circ} \mathrm{C}$ for $7 \mathrm{~min}$. The reaction of L-arginine hydrolysis by arginase was performed by incubation of the mixture containing activated arginase with $100 \mu \mathrm{l}$ of L-arginine $(0.5 \mathrm{M}$; pH 9.7) at $37{ }^{\circ} \mathrm{C}$ for $2 \mathrm{~h}$ and was terminated by the addition of $800 \mu \mathrm{l}$ of a mixture of acidic solution $\left(\mathrm{H}_{2} \mathrm{SO}_{4}: \mathrm{H}_{3} \mathrm{PO}_{4}: \mathrm{H}_{2} \mathrm{O}=1: 3\right.$ : 7). For colorimetric determination of urea, $\alpha$-isonitrosopro- piophenone (40 $\mu \mathrm{l}, 9 \%$ solution in ethanol) was added, and the mixture was incubated at $95{ }^{\circ} \mathrm{C}$ for $30 \mathrm{~min}$ and then at $4{ }^{\circ} \mathrm{C}$ for $30 \mathrm{~min}$. The urea concentration was determined spectrophotometrically. Each value was divided by the number of viable cells and expressed as the urea level/h per $10^{6}$ cells. Normalised values of means and SDs were calculated.

Intracellular reactive oxygen species (ROS) assay. Intracellular ROS levels were measured using 2'7'-dichlorodihydro-fluorescein diacetate (carboxy-H2DCFDA, Invitrogen), which was converted into a non-fluorescent derivative (carboxy-H2DCF) by intracellular esterases as described previously (Burke and Lewis, 2002). Briefly, PMs and $\mathrm{MG}$ cells were incubated with PBS containing $10 \mu \mathrm{M}$ carboxy-H2DCFDA for $20 \mathrm{~min}$ at $37^{\circ} \mathrm{C}$. A short recovery time was allowed for the cellular esterases to hydrolyse the acetoxymethyl ester or acetate groups and render the dye responsive to oxidation. The cells were then transferred to polystyrene tubes with cell-strainer caps (Falcon, Becton Dickinson, USA) and analysed by flow cytometry (excitation: $488 \mathrm{~nm}$, emission: $525 \mathrm{~nm}$ ). Only living cells, gated according to scatter parameters, were used for the analysis. Results were presented as mean fluorescence per cell.

Phagocytosis assay. The flow cytometry phagocytosis assay was performed as described earlier (Taylor and Colgan, 2017). FITC labelled Staphylococcus aureus Cowan I cells (collection of the Department of Microbiology and Immunology of ESC Institute of Biology and Medicine of Taras Shevchenko National University of Kyiv) were used as a phagocytosis object. Fluorescence of PMs and MG cells with ingested bacteria was determined by flow cytometry. The results were registered as phagocytosis index (PhI) that was calculated by the following formula: [Gmeanpos/ Ppos] - [Gmeanneg/ Pneg], where Ppos - percent of positive cells, Gmeanpos - mean channel fluorescence, Pneg - percent of positive cells in the negative control, Gmeanneg mean channel fluorescence of the negative control.

Phenotypic marker expression. Examination of the expression of phagocyte phenotypic markers (CD14 (BioLine) and CD206 (Biolegend)) was performed by flow cytometry.

Statistical analysis. Statistical analysis was performed by GraphPad Prism version 5.04 for Windows (GraphPad Software, San Diego, California USA, www.graphpad.com). To determine statistical significance of data, two-way ANOVA followed by a Bonferroni post-test was used. A value of $p<0.05$ were considered as significant.

\section{RESULTS}

Isolated rat PMs and MG were subjected to either normoxia $\left(21 \% \mathrm{O}_{2}\right)$ or hypoxia $\left(3 \% \mathrm{O}_{2}\right)$ for 24 hours, and the surface expression levels of markers CD206 and CD14 were measured by flow cytometry. The exposure to hypoxic conditions per se led to the up-regulation of mannose receptor CD206 in PMs and MG (Fig.1 A-B) and reduced CD14 ex- 

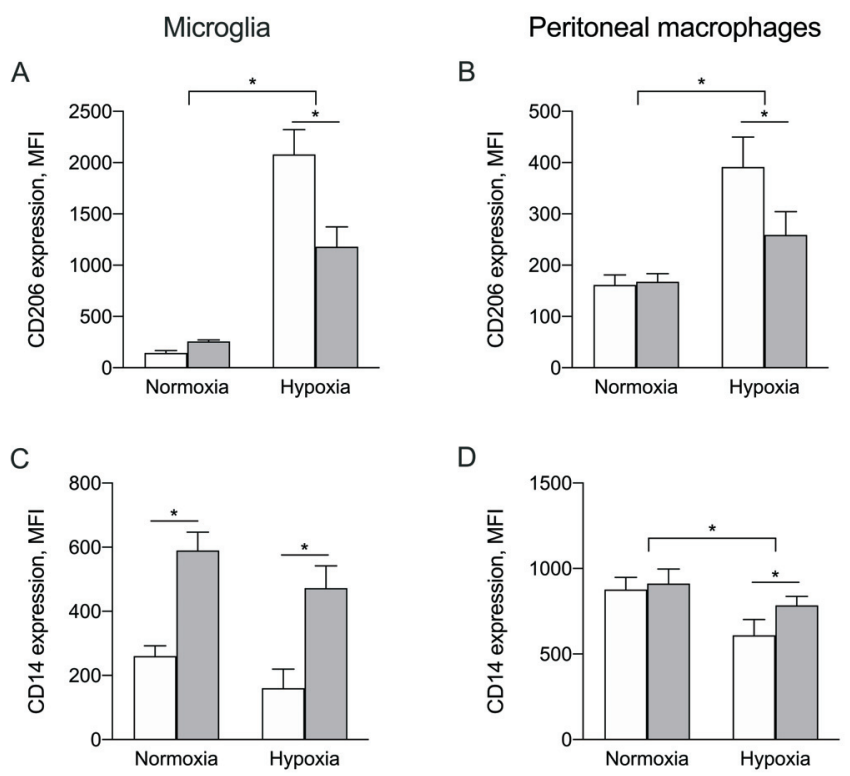

$\square$ Untreated $\square$ Larifan

Fig. 1. Cell surface expression of CD206 and CD14 by microglia (MG) and rat peritoneal macrophages (PMs) under Larifan treatment in normoxia and hypoxia: expression of CD206 in MG (A) and PMs (B), expression of CD14 in MG (C) and PMs (D). The results are displayed as the mean fluorescence intensity (MFI) $+/-\mathrm{SD}(\mathrm{n}=3, * p<0.05, * * * p<0.001$, two-way ANOVA followed by Bonferroni post-test).

pression in PMs (Fig. 1 D). This indicated a TRMs shift towards the anti-inflammatory (M2) phenotype. PMs and MG in a normoxic condition responded to the treatment with bacteriophage-derived dsRNA (Larifan) differently. PMs did not exhibit a significant expression change for the aforementioned phenotypic markers (Fig. 1 B, D). Unlike PMs, TLR3 agonist exposure in MG augmented both CD206 and CD14 surface expression (Fig. 1 A, C). In both hypoxic TRM populations, treatment with Larifan opposed the stimulatory effect of hypoxia on CD206 expression and prevented down-regulation of CD14 expression (Fig. 1 A-D). This suggested that the TLR3 agonist Larifan can interrupt the M2 phenotypic shift in hypoxic TRMs.

To further investigate the functional polarisation of macrophages, we measured arginase activity and evaluated nitric oxide (NO) production. Arginase is an enzyme that converts arginine to polyamines, proline and ornithine, which can contribute to wound healing and matrix deposition (Munder, 2009). As arginase competes with the inducible NO synthase (iNOS) for their common substrate - arginine, arginase can down-regulate the NO production (Corraliza et al., 1995; Morris, 2007). Thus, both represent a relatively straightforward set of markers to follow M1 versus M2 phenotypes. As expected, hypoxia increased the arginase activity and lowered NO production. Treatment with Larifan under hypoxia increased the arginase activity; however, it decreased the NO metabolite level, especially in PMs (Fig. 2 A-D). Interestingly, in normal conditions, treatment of PMs with Larifan resulted in the opposite effect and arginase activity was decreased, accompanied by a slight increase in NO metabolite production, which is characteristic
Microglia

A

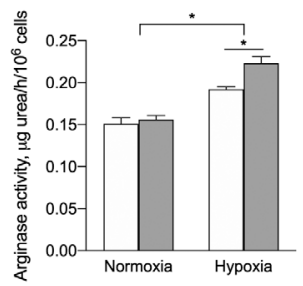

C

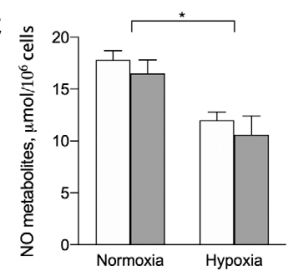

E

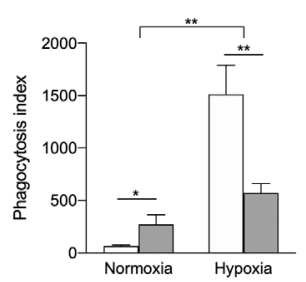

G

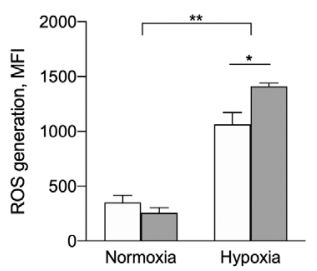

Peritoneal macrophages

B

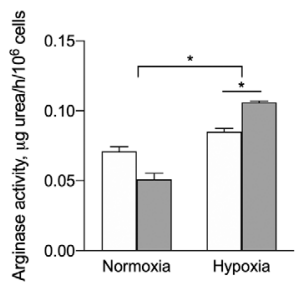

D

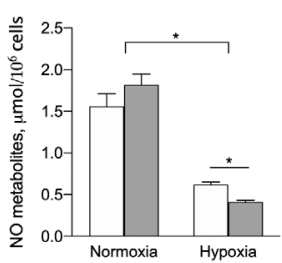

F

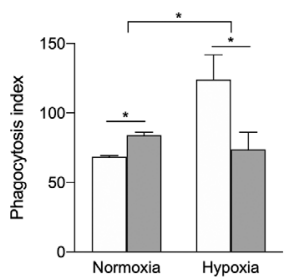

$\mathrm{H}$

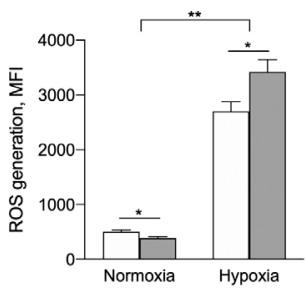

Untreated

Larifan

Fig. 2. Functional polarisation of rat microglia (MG) and peritoneal macrophages (PMs) under Larifan treatment in normoxia and hypoxia: arginase activity (A, B), level of NO metabolites (C, D), phagocytosis in$\operatorname{dex}(\mathrm{E}, \mathrm{F})$ and ROS generation $(\mathrm{G}, \mathrm{H})(\mathrm{n}=3, * p<0.05, * * p<0.01$, two-way ANOVA followed by Bonferroni post-test).

for the switch towards an M1-like functional profile (Fig. 2 A-D).

Phagocytosis was also measured as one of the fundamental properties of all subpopulations of macrophages. Treatment with Larifan was associated with a higher phagocytosis index under normal conditions in rat PMs and MG (Fig. 2 E-F). Under hypoxic conditions, we also observed an increase in the phagocytic index in both rat PMs and MG. Treatment of macrophages with Larifan under hypoxic conditions resulted in a decrease of the phagocytic index (Fig. 2 E-F).

Increased reactive oxygen species (ROS) generation was observed under hypoxia in both PMs and MG. In the presence of Larifan, ROS generation increased under hypoxic conditions (Fig. 2 G-H); however, it decreased in normoxia, especially in PMs (Fig. $2 \mathrm{H}$ ). 


\section{DISCUSSION}

TRMs play a vital role in the immunosurveillance and the maintenance of tissue homeostasis. They are also essential in the initiation and resolution of inflammatory processes, which makes them relevant therapeutic targets (Kumar and Bhat, 2019). In our experiments, we exposed TRMs of different locations to distinct danger signals (PAMPs and hypoxia) used alone and in combination to compare their activation patterns. For this purpose, we used two phenotypic markers (CD14 and CD206) and metabolic characteristics, which have been commonly used for the evaluation of macrophage polarised activation. CD14 and CD206 were chosen instead of a widely used set of macrophage phenotypic markers due to the latter's controversial validity for the evaluation of MG polarisation. CD14 is constitutively expressed by all TRMs, although by MG to a significantly lesser extent than PMs (Melief et al., 2016). Macrophage maturation, as well as their pro-inflammatory activation, are accompanied by the progressive increase of CD14 expression (Wu et al., 2019). CD206 is expressed predominantly by tissue sentinels like TRMs, including PMs and MG, as well as by dendritic cells (RégnierVigouroux, 2003; Taylor et al., 2005). CD206 is widely recognised as a typical M2 (anti-inflammatory shifted) phagocyte marker. Nevertheless, inflamed MG can up-regulate CD206 as well (Lee et al., 2020). It is necessary to point out that basal phenotypic and metabolic characteristics slightly differ in resting PMs and MG. PMs were characterised by expected higher surface expression of CD14 as well as lower arginase activity and NO generation, as compared to MG. The response pattern of normoxic PMs and MG to bacteriophage-derived dsRNA (Larifan) differed. PMs did not change phenotypic marker expression; however, it shifted their arginine metabolism to the down-regulation of arginase activity and decreased ROS generation. These are signs of pro-inflammatory polarised activation. MG strongly up-regulated phagocytic activity and surface expression of CD14, as well as caused moderate CD206 expression. Such an activation pattern cannot be considered as pro-inflammatory or anti-inflammatory. One can suggest that MG exposure to PAMPs simultaneously activates these cells to immunosurveillance and tissue repair.

Macrophages under hypoxic conditions polarise towards a M2-like phenotype, presumably as a response to the damage caused by hypoxia (Ke et al., 2019). Here, we confirmed this observation and showed that rat PMs and MG cells under hypoxia indeed up-regulated M2-like phenotypic marker CD206 and caused a decrease of CD14 expression. This was accompanied by the increased ROS generation and arginase activity and a lower NO metabolite level — all of which are features associated with macrophage M2-like phenotype. It is necessary to point out that MG up-regulated their phagocytic activity in response to hypoxia at a greater extent.

Macrophage treatment with Larifan under hypoxia lowered the surface expression of CD206 and increased CD14 expression. It appears that Larifan can polarise TRMs towards a M1-like phenotype. However, we did not observe a shift of arginine metabolism typical for M1-polarised activation. This can probably be explained by the diverse effect of Larifan on different arginase isoforms. In mammals, arginase exists in two isoforms: arginase-I and arginase-II. In TRMs, both arginases are responsible for opposite functions. Arginase-I dominates in M2 cells and is associated with the resolution of inflammation, while arginase-II is co-expressed with iNOS in M1 TRMs and takes part in inflammatory responses (Yang and Ming, 2014). The colorimetric method we used did not allow to evaluate separately the levels of arginase-I and arginase-II. Therefore, the opposite effects of Larifan on total arginase activity in normoxic and hypoxic TRMs can be explained by its opposite impact on arginase I and II.

In addition, M2-polarised activation is more complex compared with the M1 activation pathway. M2-polarised macrophages can be subdivided into M2a, M2b, M2c and M2d based upon their transcriptome. Hypoxia is mostly associated with M2c-polarised activation (Mosser and Edwards, 2008; Wang et al., 2019). Increased phagocytic activity and CD206 overexpression are distinctive features of these cells. Treatment with Larifan resulted in a decrease of phagocytic activity as well as lower CD206 expression in hypoxic TRMs. This observation is evidence in favour of the assumption that its ability to counteract with hypoxia-induced M2-polarised activation of these cells.

\section{CONCLUSIONS}

Taken together, our results indicate that bacteriophage-derived dsRNA (Larifan) can cause different patterns of normoxic TRM polarised activation, depending on their tissue genesis and attenuate hypoxia-induced TRM metabolic programming. Nonetheless, the hypoxic condition can negatively affect the interaction of these tissue sentinels with infectious agents, which might worsen the outcome of the host-pathogen interaction. Furthermore, the use of PAMPs for macrophage re-education strategies in immuno-oncology can hinder the restoration of tumour-associated macrophage antitumour properties.

\section{ACKNOWLEDGEMENTS}

The authors thank Madara Kreišmane for technical support in the manuscript preparation and Kristine Vaivode for language editing. This work was supported by the Ministry of Education and Science of Ukraine under grant No. 0116 U002527 and Latvian Council of Science, project number lzp-2020/2-0369.

\section{REFERENCES}

Bennett, M. L., Bennett, F. C. (2020). The influence of environment and origin on brain resident macrophages and implications for therapy. Nat. Neurosci. 23 (2), 157-166. 
Biswas, S. K., Mantovani, A. (2010). Macrophage plasticity and interaction with lymphocyte subsets: Cancer as a paradigm. Nat. Immunol. 11 (10), 889-896.

Burke, B., Lewis, C. E., (2002). The Macrophage. 2nd Edition. Oxford University Press. $680 \mathrm{pp}$.

Caputa, G., Castoldi, A., Pearce, E. J. (2019). Metabolic adaptations of tissue-resident immune cells. Nat. Immunol., 20 (7), 793-801.

Cherry, J. D., Olschowka, J. A., O'Banion, M. K. (2014). Are "resting" microglia more "m2"? Front Immunol., 5, 594.

Colgan, S. P., Furuta, G. T., Taylor, C. T. (2020). Hypoxia and innate immunity: Keeping up with the HIFsters. Annu. Rev. Immunol., 38, 341-363.

Corraliza, I. M., Soler, G., Eichmann, K., Modolell, M. (1995). Arginase induction by suppressors of nitric oxide synthesis (IL-4, IL-10 and PGE2) in murine bone-marrow-derived macrophages. Biochem. Biophys. Res. Commun., 206 (2), 667-673.

Dahdah, A., Gautier, G., Attout, T., Fiore, F., Lebourdais, E., Msallam, R., Daèron, M., Monteiro, R. C., Benhamou, M., Charles, N., Davoust, J., Blank, U., Malissen, B., Launay, P. (2014). Mast cells aggravate sepsis by inhibiting peritoneal macrophage phagocytosis. J. Clin. Invest., 124 (10), 4577-4589.

De Palma, M., Biziato, D., Petrova, T. V. (2017). Microenvironmental regulation of tumour angiogenesis. Nat. Rev. Cancer, 17 (8), 457-474.

Filiano, A. J., Gadani, S. P., Kipnis, J. (2015). Interactions of innate and adaptive immunity in brain development and function. Brain Res., 1617 $18-27$

Frank, M. G., Wieseler-Frank, J. L., Watkins, L. R., Maier, S. F. (2006). Rapid isolation of highly enriched and quiescent microglia from adult rat hippocampus: Immunophenotypic and functional characteristics. $J$. Neurosci. Methods, 151 (2), 121-130.

Gordon, S., Martinez, F. O. (2010). Alternative activation of macrophages: Mechanism and functions. Immunity, 32 (5), 593-604.

Guo, Y., Hong, W., Wang, X., Zhang, P., Körner, H., Tu, J., Wei, W. (2019). MicroRNAs in mcroglia: How do microRNAs affect activation, inflammation, polarization of microglia and mediate the interaction between microglia and glioma? Front Mol. Neurosci., 12, 125.

Hashimoto, D., Chow, A., Noizat, C., Teo, P., Beasley, M. B., Leboeuf, M., Becker, C. D., See, P., Price, J., Lucas, D., et al. (2013). Tissue-resident macrophages self-maintain locally throughout adult life with minimal contribution from circulating monocytes. Immunity, 38 (4), 792-804.

Jantsch, J., Schödel, J. (2015). Hypoxia and hypoxia-inducible factors in myeloid cell-driven host defense and tissue homeostasis. Immunobiology, 220 (2), 305-314

Ke, X., Chen, C., Song, Y., Cai, Q., Li, J., Tang, Y., Han, X., Qu, W., Chen, A., Wang, H., Xu, G., Liu, D. (2019). Hypoxia modifies the polarization of macrophages and their inflammatory microenvironment, and inhibits malignant behavior in cancer cells. Oncol. Lett., 18 (6), 5871-5878.

Kumar, V., Bhat, E. b. K. H. (2019). Macrophages: The potent immunoregulatory innate immune cells. In: Bhat, K. H. (Ed.). Macrophage Activation: Biology and Disease. https://www.intechopen.com/chapters/68185 (accessed 15.09.2021).

Lee, J. Y., Han, S. H., Park, M. H., Song, I. S., Choi, M. K., Yu, E., Park, C. M., Kim, H. J., Kim, S. H., Schuchman, E. H., Jin, H. K., Bae, J. S. (2020). $\mathrm{N}$-AS-triggered SPMs are direct regulators of microglia in a model of Alzheimer's disease. Nat. Commun., 11 (1), 2358.

Liu, T., Liu, F., Peng, L. W., Chang, L., Jiang, Y. M. (2018). The peritoneal macrophages in inflammatory diseases and abdominal cancers. Oncol. Res., 26 (5), 817-826.

Loža, V., Feldmane, G. (1996). Biomodulatory functions of double-stranded ribonucleic acids. Acta Med. Balt., 3 12-17.
Loža, V., Pilmane, M., Brūvere, R., Feldmane, G., Volrāte, Ā., Ose, V., Sundler, F. (1996). Double-stranded ribonucleic acids in cells during induced differentiation. Acta Med. Balt., 3 22-30.

Melief, J., Sneeboer, M. A., Litjens, M., Ormel, P. R., Palmen, S. J., Huitinga, I., Kahn, R. S., Hol, E. M., de Witte, L. D. (2016). Characterizing primary human microglia: A comparative study with myeloid subsets and culture models. Glia, 64 (11), 1857-1868.

Morris, S. M., Jr. (2007). Arginine metabolism: Boundaries of our knowledge. J. Nutr., 137 (6 Suppl 2), 1602s-1609s.

Mosser, D. M., Edwards, J. P. (2008). Exploring the full spectrum of macrophage activation. Nat. Rev. Immunol., 8 (12), 958-969.

Munder, M. (2009). Arginase: An emerging key player in the mammalian immune system. Brit. J. Pharmacol., 158 (3), 638-651.

Okabe, Y., Medzhitov, R. (2016). Tissue biology perspective on macrophages. Nat. Immunol., 17 (1), 9-17.

Pjanova, D., Mandrika, L., Petrovska, R., Vaivode, K., Donina, S. (2019). Comparison of the effects of bacteriophage-derived dsRNA and poly(I:C) on ex vivo cultivated peripheral blood mononuclear cells. Immunol. Lett. 212, 114-119.

Régnier-Vigouroux, A. (2003). The mannose receptor in the brain. Int. Rev. Cytol., 226, 321-342.

Reiner, N. E. (2009). Methods in molecular biology. Macrophages and dendritic cells. Methods and protocols. Preface. Methods Mol. Biol., 531, v-vi.

Sica, A., Mantovani, A. (2012). Macrophage plasticity and polarization: in vivo veritas. J. Clin. Invest., 122 (3), 787-795.

Skivka, L., Fedorchuk, O., Rudyk, M., Pozur, V., Khranovska, N., Grom, M. Y., Nowicky, J. (2013). Antineoplastic drug NSC631570 modulates functions of hypoxic macrophages. Cytol. Genet., 47 (5), 318-328.

Suresh, R., Mosser, D. M. (2013). Pattern recognition receptors in innate immunity, host defense, and immunopathology. Adv. Physiol. Educ., 37 (4), 284-291.

Taylor, C. T., Colgan, S. P. (2017). Regulation of immunity and inflammation by hypoxia in immunological niches. Nat. Rev. Immunol., 17 (12), 774-785.

Taylor, P. R., Martinez-Pomares, L., Stacey, M., Lin, H. H., Brown, G. D., Gordon, S. (2005). Macrophage receptors and immune recognition. Annu. Rev. Immunol., 23 901-944.

Theret, M., Mounier, R., Rossi, F. (2019). The origins and non-canonical functions of macrophages in development and regeneration. Development, 146 (9), dev 156000

Veinalde, R., Petrovska, R., Brūvere, R., Feldmane, G., Pjanova, D. (2014) Ex vivo cytokine production in peripheral blood mononuclear cells after their stimulation with dsRNA of natural origin. Biotechnol. Appl. Biochem., 61 (1), 65-73.

Vercammen, E., Staal, J., Beyaert, R. (2008). Sensing of viral infection and activation of innate immunity by toll-like receptor 3. Clin. Microbiol. Rev., 21 (1), 13-25.

Wang, L. X., Zhang, S. X., Wu, H. J., Rong, X. L., Guo, J. (2019). M2b macrophage polarization and its roles in diseases. J. Leukoc. Biol., 106 (2), $345-358$.

Wu, Z., Zhang, Z., Lei, Z., Lei, P. (2019). CD14: Biology and role in the pathogenesis of disease. Cytokine Growth Factor Rev., 48, 24-31.

Yang, Z., Ming, X. F. (2014). Functions of arginase isoforms in macrophage inflammatory responses: Impact on cardiovascular diseases and metabolic disorders. Front Immunol., 5, 533.

Zhao, Y. L., Tian, P. X., Han, F., Zheng, J., Xia, X. X., Xue, W. J., Ding, X. M., Ding, C. G. (2017). Comparison of the characteristics of macrophages derived from murine spleen, peritoneal cavity, and bone marrow. $J$. Zhejiang Univ. Sci. B., 18 (12), 1055-1063. 

MAKROFĀGIEM UN MIKROGLIJU NORMOKSIJĀ UN HIPOKSIJĀ

Pateicoties daudzveidīgajām audos rezidējošo makrofāgu funkcijām, tie tiek uzskatîti par unikāliem terapeitiskiem mērkiem. Audos rezidējošo makrofāgu aktivācijā ir iesaistīti tā dēvētie patogēnu atpazī̌anas receptori un to skaitā Toll-līdzīgie receptori (TLR). Darba mērḳis bija noteikt žurku peritoneālo makrofāgu un mikroglijas šūnu aktivācijas profilu normālos un hipoksiskos apstākḷos, kā arī izpētīt TLR3 agonista, bakteriofāgu izcelsmes dubultspirāliskās RNS (Larifan), ietekmi uz audos rezidējošo makrofāgu metabolismu in vitro. Makrofāgu raksturošanai mēs izmantojām virsmas marḳierus CD14 un CD206, noteicām arginīna metabolismu makrofāgos, kā arī to fagocitāro aktivitāti un reaktīvo skābekḷa savienojumu (ROS) veidošanos tajos. Normālos apstākḷos dažādas lokalizācijas makrofāgi reaǵēja uz Larifan iedarbību atškirīgi. Peritoneālie makrofāgi uzrādīja M1 (iekaisumu veicinošas) polarizācijas pazīmes, kamēr mikroglijas šūnu aktivāciju nevarēja uzskatīt nedz par iekaisuma procesus veicinošu, nedz arī kavējošu. Audos rezidējošie makrofāgi, neatkarīgi no lokalizācijas, uz hipoksiju reağēja ar pāreju uz M2 (iekaisumu kavējošu) polarizācijas stāvokli. Larifan vājināja hipoksijas izraisītos efektus, tomēr jāņem vērā, ka hipoksija varētu negatīvi ietekmēt makrofāgu un patogēnu dabas molekulu mijiedarbību. 